\title{
BGLAP wt Allele
}

National Cancer Institute

\section{Source}

National Cancer Institute. BGLAP wt Allele. NCI Thesaurus. Code C104591.

Human BGLAP wild-type allele is located within 1q25-q31 and is approximately $1 \mathrm{~kb}$ in length. This allele, which encodes osteocalcin protein, plays a role in the regulation of bone formation. 